\title{
PENDEKATAN PENDIDIKAN KESEHATAN TENTANG 1000 HPK TERHADAP UPAYA PENCEGAHAN STUNTING DI PUSKESMAS TAMALANREA JAYA KOTA MAKASSAR
}

\author{
Andi Hasliani, Rahmawati \\ STIKES Nani Hasanuddin Makassar \\ andi_hasliani@yahoo.com/085396468777
}

\begin{abstract}
Stunting is a condition in which a person's height is shorter than the height of other people in general. The incidence of stunting (short) children is a major nutritional problem facing Indonesia. Based on Nutritional Status Monitoring (PSG) data for the last three years, stunting has the highest prevalence compared to other nutritional problems such as malnutrition, thinness, and obesity. The purpose of this study was to determine the impact of the Health Education approach on 1000 HPK on Stunting Prevention Efforts at Puskesmas Tamalanrea Jaya Makassar. This research uses a quantitative analytic research type with a quasi experimental design study with the one group pretest-posttest design approach. This research was conducted at the Puskesmas Tamalanrea Jaya Makassar from March to September 2020. The population in this study were pregnant women in the first trimester with restrictions on inclusion criteria in the working area of the Puskesmas and recorded in medical records. The sampling technique used purposive sampling with a sample size of as many as 50 homogeneous respondents based on population size considerations. The research results were processed using SPSS, the data normality test showed that if the data were normally distributed, the test used was the paired t test with a sig value of $0.000<\alpha 0.05$. The conclusion of this study is that there is a significant difference between the efforts to prevent stunting by pregnant women before and after health education on the first 1000 days of birth.
\end{abstract}

Keywords: Stunting, 1000 HPK, Health Education

\section{ABSTRAK}

Stunting adalah sebuah kondisi dimana tinggi badan seseorang ternyata lebih pendek dibanding tinggi badan orang lain pada umumnya. Kejadian balita stunting (pendek) merupakan masalah gizi utama yang dihadapi Indonesia. Berdasarkan data Pemantauan Status Gizi (PSG) selama tiga tahun terakhir, pendek memiliki prevalensi tertinggi dibandingkan dengan masalah gizi lainnya seperti gizi kurang, kurus, dan gemuk. Stunting dapat dicegah dengan pemberian pemberian pendidikan kesehatan tentang 1000 Hari Pertama Kelahiran. Tujuan penelitian ini adalah diketahuinya dampak pendekatan Health Education tentang 1000 HPK terhadap Upaya Pencegahan Stunting di Puskesmas Tamalanrea Jaya Makassar. Penelitian ini menggunakan jenis penelitian kuantitatif analitik dengan studi desain quasi ekspriment dengan pendekatan the one group pretest-posttest design. Penelitian ini telah dilaksanakan di Puskesmas Tamalanrea Jaya Makassar bulan Maret sampai dengan September 2020. Populasi dalam penelitian ini adalah ibu hamil trimester 1 dengan pembatasan kriteria inklusi yang berada di wilayah kerja Puskesmas dan terdata di rekam medik, teknik sampling menggunakan purposive sampling dengan besaran sampel sebanyak 50 responden yang homogen berdasarkan pertimbangan jumlah populasi. Hasil penelitian diolah menggunakan SPSS, uji normalitas data menunjukkan jika data terdistribusi normal sehingga uji yang digunakan adalah uji t berpasangan dengan hasil nilai sig $0,000<a 0,05$. Kesimpulan penelitian ini adalah ada perbedaan signifikan antara upaya pencegahan stunting yang dilakukan ibu hamil sebelum dan sesudah dilakukan pendidikan kesehatan tentang 1000 Hari Pertama Kelahiran.

Kata kunci : Stunting, 1000 HPK, Health Education

\section{PENDAHULUAN}

Indonesia masih menghadapi permasalahan gizi yang berdampak serius terhadap kualitas sumber daya manusia (SDM). Salah satu masalah kekurangan gizi yang masih cukup tinggi di Indonesia terutama stunting dan wasting pada balita serta masalah anemia dan kurang energi kronik pada ibu hamil. Masalah kekurangan gizi pada ibu hamil ini dapat menyebabkan berat bayi lahir rendah dan kekurangan gizi pada balita, termasuk stunting.

Kejadian balita pendek atau biasa disebut dengan stunting merupakan salah satu masalah gizi yang dialami oleh balita di dunia saat ini. Pada tahun 2017 22,2\% atau sekitar 150,8 juta balita di dunia mengalami stunting. Pada tahun 2017, lebih dari setengah balita stunting di dunia berasal dari Asia (55\%) sedangkan lebih dari sepertiganya (39\%) tinggal di Afrika. Dari 83,6 juta balita stunting di Asia, proporsi terbanyak berasal dari Asia Selatan $(58,7 \%)$. Data prevalensi balita stunting yang dikumpulkan World Health Organization (WHO), Indonesia termasuk ke dalam negara ketiga dengan prevalensi tertinggi di regional Asia Tenggara/SouthEast Asia Regional (SEAR). Rata-rata prevalensi balita stunting di Indonesia tahun 2005-2017 adalah 36,4\% sedangkan menurut data Riskesdas Tahun 2018 data 
stunting mencapai 30,8\%. (Kemenkes RI, 2018)

Kejadian balita stunting (pendek) merupakan masalah gizi utama yang dihadapi Indonesia. Berdasarkan data Pemantauan Status Gizi (PSG) selama tiga tahun terakhir, pendek memiliki prevalensi tertinggi dibandingkan dengan masalah gizi lainnya seperti gizi kurang, kurus, dan gemuk. Prevalensi balita pendek mengalami peningkatan dari tahun 2016 yaitu $27,5 \%$ menjadi $29,6 \%$ pada tahun 2017. (Kemenkes RI, 2018) (Kemenkes RI, 2018)

Prevalensi balita pendek di Indonesia cenderung statis. Hasil Riset Kesehatan Dasar (Riskesdas) tahun 2007 menunjukkan prevalensi balita pendek di Indonesia sebesar $36,8 \%$. Pada tahun 2010, terjadi sedikit penurunan menjadi $35,6 \%$. Namun prevalensi balita pendek kembali meningkat pada tahun 2013 yaitu menjadi $37,2 \%$. Prevalensi balita pendek selanjutnya akan diperoleh dari hasil Riskesdas tahun 2018 yang juga menjadi ukuran keberhasilan program yang sudah diupayakan oleh pemerintah. (Kemenkes $\mathrm{RI}, 2018$ )

Stunting dapat terjadi sebagai akibat kekurangan gizi terutama pada saat 1000 HPK. Pemenuhan gizi dan pelayanan kesehatan pada ibu hamil perlu mendapat perhatian untuk mencegah terjadinya stunting. Stunting akan berpengaruh terhadap tingkat kecerdasan anak dan status kesehatan pada saat dewasa. Akibat kekurangan gizi pada 1000 HPK bersifat permanen dan sulit untuk diperbaiki. (Hudaya, 2018)

Untuk meningkatkan pengetahuan dan sikap maka perlu diberikan pendidikan kesehatan. Pendidikan kesehatan merupakan bagian dari promosi kesehatan yaitu proses untuk meningkatkan kemampuan masyarakat dalam memelihara dan menjaga kesehatannya dan tidak hanya melibatkan diri untuk memperbaiki pengetahuan, sikap saja, tetapi juga memperbaiki lingkungan (baik fisik maupun non fisik) dalam rangka memelihara dan menjaga kesehatan mereka (Notoatmodjo, 2012).

Untuk mencegah dan mengatasi masalah stunting, masyarakat perlu dididik agar memahami pentingnya gizi bagi anak balita. Secara aktif indonesia turut serta dalam komitmen global (SUN- Scalling UP Nutrition) atau dikenal dengan Gerakan
Nasional Sadar Gizi dalam rangka Percepatan Perbaikan Gizi pada seribu hari pertama kehidupan. Tujuannya adalah untuk meningkatkan keadaan gizi, kesehatan masayarakat dan pembangunan. Program tersebut dikhususkan untuk penanganan gizi sejak seribu hari dari masa kehamilan hingga anak usia 2 tahun (Kemenkes RI, 2018)

Stunting dalam jangka panjang berdampak buruk tidak hanya terhadap tumbuh kembang anak tetapi juga terhadap perkembangan emosi yang berakibat pada kerugian ekonomi. Mulai dari pemenuhan gizi yang baik selama 1000 hari pertama kehidupan anak hingga menjaga lingkungan agar tetap bersih dan sehat dapat meminimalkan terjadinya staunting. Pemberian health education pada ibu hamil sebagai wujud dari realisasi 1000 HPK untuk mencegah stunting perlu dilakukan agar ibu hamil mampu secara mandiri mempersiapkan diri melahirkan generasi penerus yang berkualitas dan bebas stunting. Berdasarkan hal tersebut penulis tertarik untuk melakukan penelitian dengan judul "Pendekatan Health Education tentang 1000 HPK terhadap Upaya Pencegahan Stunting di Puskesmas Tamalanrea Jaya Makassar".

\section{METODE}

\section{Desain, tempat dan waktu}

Penelitian ini menggunakan jenis penelitian kuantitatif analitik dengan studi desain quasi ekspriment dengan pendekatan the one group pretest-posttest design (Dahlan, 2014). Penelitian ini tidak menggunakan kelompok pembanding namun telah menggunakan test awal sehingga dapat diketahui besarnya perubahan upaya pencegahan stunting sejak kehamilan yang dilakukan oleh ibu hamil setelah pemberian health education tentang 1000 Hari Pertama Kelahiran (HPK).

(Buchari, 2013) Secara sederhana desain penelitian dapat digambarkan sebagai berikut

$01--$ Tes awal
$01=02$
$02=$ Tes Akhir
$X=$ Perlakuan (Health Education tentang
1000 HPK).
Penelitian ini akan dilaksanakan di Wilayah Kerja Puskesmas Tamalanrea Jaya pada bulan Januari sampai dengan Bulan Agustus 2020. 


\section{Populasi dan Subjek Penelitian}

Populasi dalam penelitian ini adalah ibu hamil trimester 1 dengan pembatasan kriteria inklusi yang berada di wilayah kerja Puskesmas dan terdata di rekam medik, teknik sampling menggunakan purposive sampling dengan besaran sampel sebanyak 50 responden yang homogen berdasarkan pertimbangan jumlah populasi. Adapun kriteria inklusi pada penelitian ini adalah :

1. Ibu hamil yang berada di wilayah kerja Puskesmas Tamalanrea Jaya Makassar

2. Ibu hamil tanpa penyulit

Kriteria eksklusi pada penelitian ini adalah ibu hamil trimester 1 yang tidak bersedia dijadikan responden.

Jenis dan Cara Pengumpulan Data.

Data yang dikumpulkan dalam penelitian ini adalah data primer dengan menggunakan kuesioner yang telah dilakukan uji validitas dan realibilitas. Kuesioner dibagikan kepada responden dengan dua tahap. Tahap pertama responden dibagikan kuesioner untuk mengukur upaya-upaya yang telah dilakukan untuk mencegah stunting, setelah itu responden diberikan health education terkait 1000 Hari Pertama Kelahiran yang didalamnya memuat pengetahuan stunting, penyebab dilihat dari kecukupan gizi dalam periode 1000 HPK dan dampak yang dapat ditimbulkan oleh stunting secara jangka pendek maupun jangka panjang. Bulan Agustus dilakukan kembali pengukuran untuk mengetahui upaya-upaya apa saja yang telah dilakukan oleh ibu hamil untuk mencegah stunting selama kehamilannya.

\section{Pengolahan dan analisis data}

Analisis data dilakukan dua kali untuk sampel yang sama. Analisis pertama dilakukan setelah dilakukan pre test terkait upaya-upaya yang telah dilakukan ibu hamil untuk mencegah stunting. Selanjutnya analisis kedua setelah dilakukan posttest, data dikumpulkan dan diolah untuk mengetahui perbedaan perilaku ibu hamil setelah dilakukan healt education. Data yang diperoleh kemudian diuji, jika data berdistribusi normal menggunakan uji $t$ berpasangan dan jika tidak berdistribusi normal menggunakan uji Wilcoxon dengan tingkat kemaknaan $\alpha=0,05$ (Stang, 2014).

HASIL

Analisis Univariat

Tabel 1.

Karakteristik Responden.

\begin{tabular}{|c|c|c|}
\hline Karakteristik Subjek & $\mathbf{N}$ & $\%$ \\
\hline $\begin{array}{l}\text { Umur } \\
<20 \text { dan }>35 \text { Tahun } \\
20-35 \text { Tahun }\end{array}$ & $\begin{array}{l}21 \\
29 \\
\end{array}$ & $\begin{array}{l}42 \\
58 \\
\end{array}$ \\
\hline $\begin{array}{l}\text { Pendidikan } \\
\text { Rendah } \\
\text { Menengah } \\
\text { Perguruan Tinggi }\end{array}$ & $\begin{array}{c}8 \\
29 \\
13\end{array}$ & $\begin{array}{l}16 \\
58 \\
26\end{array}$ \\
\hline $\begin{array}{l}\text { Pekerjaan } \\
\text { IRT } \\
\text { Wiraswasta } \\
\text { PNS } \\
\end{array}$ & $\begin{array}{c}16 \\
27 \\
7 \\
\end{array}$ & $\begin{array}{l}32 \\
54 \\
14\end{array}$ \\
\hline $\begin{array}{l}\text { Umur Kehamilan } \\
\text { Trimester I } \\
\text { Trimester II } \\
\text { Trimester III }\end{array}$ & $\begin{array}{l}10 \\
21 \\
19\end{array}$ & $\begin{array}{l}20 \\
42 \\
38\end{array}$ \\
\hline $\begin{array}{l}\text { Pretest } \\
\text { Tinggi } \\
\text { Sedang } \\
\text { Rendah } \\
\end{array}$ & $\begin{array}{c}7 \\
13 \\
30\end{array}$ & $\begin{array}{l}14 \\
26 \\
60\end{array}$ \\
\hline $\begin{array}{l}\text { Posttest } \\
\text { Tinggi } \\
\text { Sedang } \\
\text { Rendah }\end{array}$ & $\begin{array}{c}17 \\
28 \\
5\end{array}$ & $\begin{array}{l}34 \\
56 \\
10\end{array}$ \\
\hline
\end{tabular}

1. Umur

Vol. XV No. 2, Desember 2020

DOI: https://doi.org/10.32382/medkes.v15i2.1704 
Data responden yang berumur < 20 dan > 35 Tahun sebanyak 21 responden $(42 \%)$ dan responden yang berumur $20-35$ tahun sebanyak 29 responden (58\%).

2. Pendidikan

Data responden yang berpendidikan SD dan SMP sebanyak 8 Responden (16\%), responden yang berpendidikan SMA sebanyak 29 orang $(58 \%)$ dan responden yang berpendidikan DIPLOMA dan SARJANA sebanyak 13 Responden (26\%).

3. Pekerjaan

Data responden yang bekerja sebagai IRT sebanyak 16 Responden $(32 \%)$, responden yang bekerja sebagai wiraswasta sebanyak 27 responden (54\%) dan yang bekerja sebagai PNS sebanyak 7 responden (14\%).

4. Umur Kehamilan

Data responden dengan usia kehamilan trimester I sebanyak 10 orang $(20 \%)$, responden dengan usia kehamilan trimester II sebanyak 21 responden (42\%) dan responden dengan umur kehamilan trimester III sebanyak 19 responden (38\%)

5. Pretest

Data responden sebelum diberika pendidikan kesehatan dengan kategori tinggi sebanyak 7 responden (14\%), kategori sedang sebanyak 13 responden $(26 \%)$ dan kategori rendah sebanyak 30 responden $(60 \%)$.

6. Posttest

data bahwa responden yang melakukan upaya pencegahan stunting setelah dilakukan pendidikan kesehatan dengan kategori tinggi sebanyak 17 responden (34\%), kategori sedang sebanyak 28 responden (56\%) dan kategori rendah sebanyak 5 responden $(10 \%)$.

\section{Analisis Bivariat}

1. Uji Normalitas Data

Uji normalitas dengan menggunakan SPSS didapatkan nilai signifikansi $0,958>0,05$, maka dapat disimpulkan bahwa nilai residual berdistribusi normal sehingga uji yang dilakukan adalah Uji T berpasangan.

Tabel 2

Hasil uji normalitas data

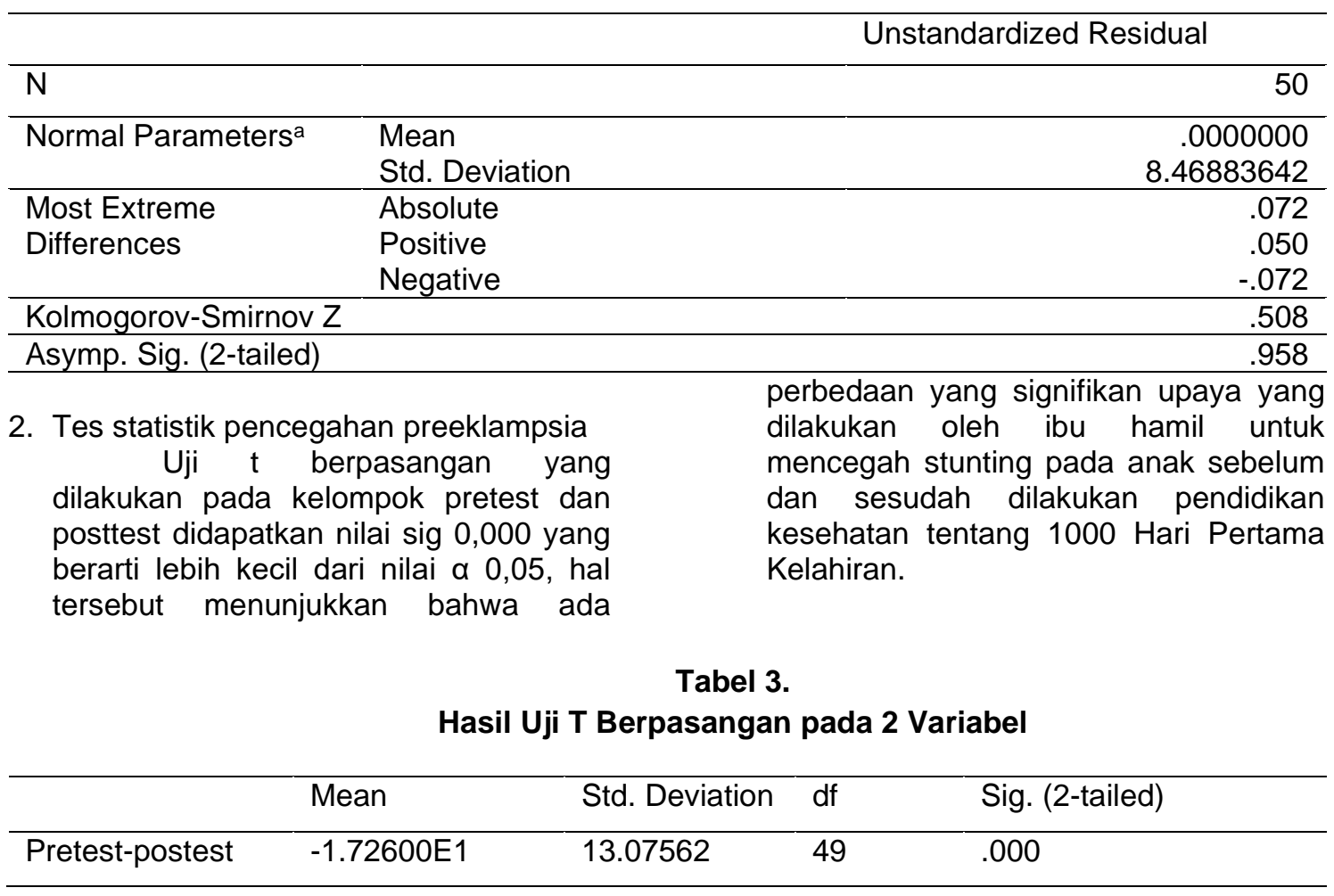




\section{PEMBAHASAN}

Hasil penelitian yang diperoleh menunjukkan ada perbedaan yang signifikan upaya yang dilakukan ibu hamil dalam mencegah stunting sebelum dan sesudah diberikan pendidikan kesehatan dengan nilai rata-rata sebelum pendidikan kesehatan adalah 59 meningkat menjadi rata-rata 72 setelah dilakukan pendidikan kesehatan.

Hasil analisis univariat dari 50 responden sebelum dilakukan pendidikan kesehatan sebanyak 30 responden $(60 \%)$ yang melakukan upaya pencegahan stunting kurang dan setelah diberikan pendidikan kesehatan yang melakukan upaya pencegahan preeklampsia kurang menurun menjadi 5 responden (10\%). Hasil ini diperkuat dengan uji t berpasangan yang dilakukan pada data sebelum dan sesudah dilakukan pendidikan kesehatan. Hasil uji t berpasangan yaitu 0,000 lebih kecil dari nilai $\alpha=0,05$ sehingga ada perbedaan yang signifikan sebelum dan sesudah dilakukan pendidikan kesehatan.

Meskipun secara garis besar berdasarkan hasil uji didapatan perbedaan yang signifikan, namun masih banyak ibu hamil yang melakukan upaya pencegahan sedang bahkan cenderung rendah, hal ini karena disebabkan dalam masyarakat ada budaya-budaya yang menjadi kepercayaan untuk berpantang pada makanan tertentu.

Penelitian ini sejalan dengan penelitian yang dilakukan oleh (Waliulu \& Ibrahim, 2018), yang meneliti pengaruh edukasi terhadap tingkat pengetahuan dan upaya pencegahan stunting anak usia balita, stunting sebelum dan sesudah edukasi dengan mean 26,20 dan 32,20, standar deviasi 1,989 dan 2,093 dengan $p$ value $=0,000$ yang menunjukan bahwa ada perbedaan mean upaya pencegahan sebelum dan sesudah edukasi.

Penelitian ini juga sejalan dengan penelitian oleh (Suryagustina dkk, 2018) dengan penelitian Pengaruh Pendidikan Kesehatan Tentang Pencegahan Stunting Terhadap Pengetahuan Dan Sikap Ibu di Kelurahan Pahandut Palangka Raya menggunakan uji wilcoxon di dapatkan adanya pengaruh pendidikan kesehatan tentang pencegahan stunting terhadap sikap ibu. Nilai pre-test dan post-test responden didapatkan nilai signifikasi $p$ value $0,000<0,05$, maka hipotesis H2 diterima artinya ada perbedaan sikapsebelum dan sesudah diberikan pendidikan kesehatan.

Stunting dapat disebabkan oleh berbagai faktor. WHO (2013) membagi penyebab terjadinya stunting pada anak menjadi 4 kategori besar yaitu faktor keluarga dan rumah tangga, makanan tambahan/ komplementer yang tidak adekuat, menyusui, dan infeksi. Stunting dapat mengindikasikan bahwa telah terjadi retardasi pertumbuhan akibat defisiensi zat gizi saat dalam kandungan, artinya ibu yang kurang gizi sejak awal kehamilan hingga lahir akan berisiko melahirkan anak BBLR yang juga berisiko menjadi stunting. Stunting juga dapat dicegah dengan memberikan gizi yang adekuat pada balita seperti penelitian yang dilakukan oleh (Nadimin, 2019) dengan judul Peningkatan Nilai Gizi Mikro Kudapan Lokal Melalui Subtitusi Tepung Ikan Gabus Untuk Pencegahan Stunting di Sulawesi Selatan. Hasil penelitian ini menunjukkan Kadar zat gizi tepung ikan gabus protein $73,81 \%$, besi $0,9 \%$, seng $0,42 \%$, kalsium $35,38 \%$. Jajanan lokal TIG (tepung ikan gabus) mengandung kalsium $353 \mathrm{mg}$, pospor $546 \mathrm{mg}$, besi $9 \mathrm{mg}$ dan seng $4.4 \mathrm{mg}$ setiap porsi. Penambahan TIG di atas 5\% dapat memenuhi kebutuhan gizi mikro pada anak balita sehingga stunting dapat dicegah.

Periode yang paling kritis dalam penanggulangan stunting dimulai sejak janin dalam kandungan sampai anak berusia 2 tahun yang disebut dengan periode emas (1000 hari pertama kehidupan). Oleh karena itu, perbaikan gizi diprioritaskan pada usia seribu hari pertama kehidupan yaitu 270 hari selama kehamilannya dan 730 hari pada kehidupan pertama bayi yang dilahirkannya.

Pencegahan dan penanggulangan stunting yang paling efektif pada Ibu Hamil adalah dengan memperbaiki gizi dan kesehatan ibu hamil. Ibu hamil perlu mendapat makanan yang baik. Apabila ibu hamil dalam keadaan sangat kurus atau telah mengalami Kurang Energi Kronis (KEK), maka perlu diberikan makanan tambahan kepada ibu hamil tersebut. Setiap ibu hamil juga perlu mendapat tablet tambah darah, minimal 90 tablet selama kehamilan.

\section{KESIMPULAN}

Terdapat perbedaan yang signifikan upaya yang dilakukan ibu hamil 
dalam mencegah stunting sebelum dan sesudah dilakukan pendidikan tentang 1000 HPK

\section{SARAN}

1. Untuk Puskesmas

Sebagai ujung tombak
pelayanan kesehatan paling dekat
dengan masyarakat, diharapkan kepada
pihak Puskesmas untuk terus
melakukan edukasi terkait dengan
pencegahan stunting agar upaya-upaya
yang dilakukan oleh ibu hamil dapat
maksimal dan angka kejadian stunting
nasional dapat menurun.

2. Untuk ibu Hamil

Untuk selalu memperhatikan asupan makanan, bukan hanya seberapa banyak yang dikonsumsi tapi variasi makanan yang dapat memenuhi kebutuhan janin dalam kandungan agar pertumbuhan dan perkembangan janin dapat optimal sejak dalam kandungan.

3. Untuk Peneliti Selanjutnya.

Dapat menjadikan penelitian ini sebagai referensi untuk menemukan model yang paling tepat dalam mencegah terjadinya stunting.

\section{UCAPAN TERIMAKASIH}

Kepada yang terhormat :

1. Kementrian Risek dan Teknologi/Badan Riset dan Inovasi nasional yang telah membiayai penelitian ini melalui Hibah Eksternal Skim Penelitian Dosen Pemula (PDP).

2. Ketua STIKES Nani Hasanuddin Makassar Bapak Sri Darmawan yang memberikan dukungan motivasi dan materil.

3. Kepala P3M STIKES Nani Hasanuddin Makassar, Ibu Suarnianti yang selalu memberikan motivasi kepada dosen untuk produktif menghasilkan penelitian dan pengabdian pada msyarakat

4. Kepala Puskemas Tamalanrea Jaya yang telah memberi izin melaksanakan penelitian di Puskesmas Bangkala

5. Responden yang bersedia bekerjasama memberikan data dan informasi sehingga penelitian ini dapat terlaksana.

\section{DAFTAR PUSTAKA}

Buchari, L. (2013). Metode Penelitian Kesehatan, Metode IImiah Penulisan Skripsi, Tesis dan Disertasi. Jakarta: Yayasan Pustaka Obor Indonesia.

Dahlan, M. S. (2014). Pintu Gerbang memahami statistic, metodologi dan epidemologi. Jakarta: Sagung Seto.

Hudaya. (2018). Cegah Stunting itu Penting. Warta Kesmas Kementrian Kesehatan Republik Indonesia.

Kemenkes RI. (2018). Situasi Balita Pendek (stunting) di Indonesia. Buletin Jendela Dan Informasi Kesehatan.

Nadimin, L. (2019). Peningkatan Nilai Gizi Mikro Kudapan Lokal Melalui Subtitusi Tepung Ikan Gabus untuk Pencegahan Stunting di Sulawesi Selatan, 8153, 152-157. http://journal.poltekkesmks.ac.id/ojs2/index.php/mediakeseh atan/article/view/1021/777 Diakses 10 September 2020.

Notoatmodjo. (2012). Promosi Kesehatan dan Perilaku Kesehatan. Jakarta: Rineka Cipta.

Stang. (2014). Cara Praktis Penentuan uji statistic dalam penelitian kesehatan dan kedokteran. Jakarta: Mitra Wacana Media.

Suryagustina dkk. (2018). Pendidikan Kesehatan Tentang Pencegahan Stunting Terhadap Pengetahuan Dan Sikap lbu di Kelurahan Pahandut Palangka Raya, 9(2). https://ojs.dinamikakesehatan.unism.a c.id/index.php/dksm/article/view/373/2 98. Diakses 10 September 2020.

Waliulu, S. H., \& Ibrahim, D. (2018). Pengaruh edukasi terhadap tingkat pengetahuan dan upaya pencegahan stunting anak usia balita, http://forikes-

ejournal.com/index.php/SF/article/vie w/sf9407/9407. Diakses 10 September 2020. 